\title{
THERMAL ENERGY STORAGE
} FOR BUILDING HEATING AND
COOLING APPLICATIONS QUARTERLY PROGRESS REPORT APRIL-JUNE 1976

H. W. HOFFMAN R. J. KEDL

\section{OAK RIDGE NATIONAL LABORATORY}




\section{DISCLAIMER}

This report was prepared as an account of work sponsored by an agency of the United States Government. Neither the United States Government nor any agency Thereof, nor any of their employees, makes any warranty, express or implied, or assumes any legal liability or responsibility for the accuracy, completeness, or usefulness of any information, apparatus, product, or process disclosed, or represents that its use would not infringe privately owned rights. Reference herein to any specific commercial product, process, or service by trade name, trademark, manufacturer, or otherwise does not necessarily constitute or imply its endorsement, recommendation, or favoring by the United States Government or any agency thereof. The views and opinions of authors expressed herein do not necessarily state or reflect those of the United States Government or any agency thereof. 


\section{DISCLAIMER}

Portions of this document may be illegible in electronic image products. Images are produced from the best available original document. 


\author{
Printed in the United States of America. Available from \\ National Technical Information Service \\ U.S. Department of Commerce \\ 5285 Port Royal Road, Springfield, Virginia 22161 \\ Price: Printed Copy $\$ 3.50$; Microfiche $\$ 2.25$
}

\begin{abstract}
This report was prepared as an account of work sponsored by the United States Government. Neither the United States nor the Energy Research and Development Administration/United States Nuclear Regulatory Commission, nor any of their employees, nor any of their contractors, subcontractors, or their employees, makes any warranty, express or implied, or assumes any legal liability or responsibility for the accuracy, completeness or usefulness of any information, apparatus, product or process disclosed, or represents that its use would not infringe privately owned rights.
\end{abstract}


THERMAL ENERGY STORAGE FOR BUILDING HEATING AND COOLING APPLICATIONS QUARTERLY PROGRESS REPORT FOR PERIOD APRIL-JUNE 1976

H. W. Hoffman and R. J. KedI

(Manuscript Completed July 16, 1976)

Date Published: November 1976

NOTICE: This document contains information of a prellminary nature and was prepared primarily for internal use at the Oak Ridge National Laboratory. It is subject to revision or correction and therefore does not represent a final report.

OAK RIDGE NATIONAL LABORATORY

Oak Ridge, Tennessee 37830

operated by

UNION CARB IDE CORPORATION

for the

ENERGY RESEARCH AND DEVELOPMENT ADMINISTRATION 
THIS PAGE

\section{WAS INTENTIONALLY LEFT BLANK}


SUMMARY . . . . . . . . . . . . . . . . . v

1. INTRODUCTION . . . . . . . . . . . . . . 1

2. PROGRAM OBJECTIVE ................ . . 1

3. ORNL TECHNICAL STUDIES . . . . . . . . . . 2

3.1 Mathematical and Physical Modeling ....... 2

3.2 Subsystems for Solar Application . . . . . . 2

3.3 Thermodynamic Properties and Interactions . . . 2

4. INDUSTRIAL PARTICIPATION ............. 3

5. PRogram Management .............. 4

5.1 subcontracts ............. 4

5.2 Proposal Reviews ............. 4

5.3 Meetings . . . . . . . . . . . 6

5.4 visits ................. . 7

5.5 Publications . . . . . . . . . . . 7

5.6 Program Plan . . . . . . . . . . . . 8

Appendix A-1: NATO Conference Sumary . . . . . . 9 


\section{THIS PAGE}

\section{WAS INTENTIONALLY \\ LEFT BLANK}


SUMMARY

This document is the first in a series of quarterly progress reports covering activities funded at ORNL by the ERDA Division of Energy Storage Systems to develop thermal energy storage (TES) technology applicable to building heating and cooling. Studies to be carried out will emphasize latent heat storage in that sensible heat storage is held to be an essentlally existing technology.

Development of a time-dependent analytical model of a TES system charged with a phase-change materlal was started. A report on TES subsystems for application to solar energy sources is nearing completion. Studies Into the physical chemistry of TES materials were inftiated. Preliminary data were obtained on the melt-freeze cycle behavior and viscosities of sodium thiosulfate pentahydrate and a mixture of Glauber's salt and Borax; 11mited melt-freeze data were obtained on two paraffin waxes.

A subcontract was signed with Monsanto Research Corporation for studies on form-stable crystalline polymer pellets for TES; subcontracts are being negotlated with four other organizations (Clemson University, Dow Chemical Company, Franklin Institute, and Suntek Research Assoclates). Review of 10 of 13 unsolicited proposals received was completed by the end of June 1976. 
THERMAL ENERGY STORAGE FOR

BUILDING HEATING AND COOLING APPLICATIONS

QUARTERLY PROGRESS REPORT FOR PERIOD

APRIL-JUNE 1976

H. W. Hoffman and R. J. Kedl

\section{INTRODUCTION}

This is the first in a series of quarterly reports covering activities funded at ORNL by the ERDA Diviston of Energy Storage Systems (DESS) to develop thermal energy storage (TES) technology applicable to building heating and cooling. The low funding level during the first three quarters of FY 1976 severely constrained the technical effort; however, much was accomplished during this early period in assisting ERDA with defining overall program goals, reviewing proposals, and outlining ORNL responsibilities. To provide some tie with this earlier work, the present report covers activities for the larger period January-June 1976.

\section{PROGRAM OBJECTIVE}

This program provides management and technical support to ERDA in developing thermal energy storage (TES) systems for use with solar or waste heat energy sources and for peak shaving by the consumer in building heating and cooling. This objective will be pursued with the general guideline that engineering feasibility and concept demonstration will be the province of industrial participants and concept feasibility and long-term generic R\&D, of universities and national laboratories. Studies performed will emphasize latent and chemical reaction heat storage in that sensible heat storage is held to be an essentially existing technology (albelt with commercialization problems and low-energy density 11mitations). 


\section{ORNL TECHNICAL STUDIES (TASK 2)}

\subsection{Mathematical and Physical Modeling - Task 2.1 (M. E. LaVerne)}

Development of a time-dependent analytical model of a TES system charged with a phase-change material was started. Current effort is directed to defining the problem and obtaining background information. The moving boundary problem (Stefan problem), as in the melting or freezing of a PCM, is difficult but important and is receiving a great deal of attention by applied mathematicians. Our approach here is to utilize existing solutions to describe the behavior of a. TES system. The TES model will be coupled analytically to existing overall performance models of solar collectors and applications; thus a realistic appraisal of the entire Solar/TES/Application system will be avallable.

\subsection{Subsystems for Solar Application - Task 2.2 (C. L. Segaser)}

This study, inftiated at the request of OTA (see Section 5.5), is being extended to include an economic evaluation of TES subsystems. The compass of the report is broad and should provide significant rationale tor TES application with the solar energy source. Considered are loads ranging from single-tamily residences to citles of 30,000 , including 100-unit apartment buildings, storage capacities from 60 to $3.6 \times 10^{6} \mathrm{Kw}$. hrs, and storage temperatures from 100 to $1000^{\circ} \mathrm{F}$. The report should be completed by the end of the transition period.

\subsection{Thermodynamic Properties and Interactions - Task 2.4 (S. Cantor and D. E. Ileather'1y)}

Studies were initiated into the physical chemistry of materials that: can be used to store thermal energy in individual homes and such larger buildings as apartment houses, department stores, etc.

Two materials currently belng investigated for phase-change storage sodium thoisulfate pentahydrate $\left(\mathrm{Na}_{2} \mathrm{~S}_{2} \mathrm{O}_{3} \cdot 5 \mathrm{H}_{2} \mathrm{O}\right)$ for heat storage and a mixture of $\mathrm{Na}_{2} \mathrm{SO}_{4} \cdot 10 \mathrm{H}_{2} \mathrm{O}-\mathrm{NaCl}-\mathrm{NH}_{4} \mathrm{Cl}-\mathrm{Na}_{2} \mathrm{~B}_{4} \mathrm{O}_{7} \cdot 10 \mathrm{H}_{2} 0$-thickener (70-11-103-6 wt\%) for cold storage - were studied in regard to melting and freezing 
behavior. Ne1ther material behaved as favorably as reported. ${ }^{1}$ Reagent grade $\mathrm{Na}_{2} \mathrm{~S}_{2} \mathrm{O}_{3} \cdot 5 \mathrm{H}_{2} \mathrm{O}$ melted over a range of $46.5^{\circ} \mathrm{C}$ to above $66^{\circ} \mathrm{C}$ rather than congruently; supercooling of the molten material was observed in all 12 of the temperature cycles. The coolness medium (without thickener) showed supercooling to $25^{\circ} \mathrm{C}$ in quiescent liquid and to $\sim 9.6^{\circ} \mathrm{C}$ in stirred 11quid; the freezing temperature was $10.6^{\circ} \mathrm{C}$ vs the $12.8^{\circ} \mathrm{C}$ reported by Telkes. ${ }^{\text {I }}$

Paraffin waxes are also belng examined as heat storage materials. Two waxes, supplied by Quaker State Corporation, were studied with the following results:

\begin{tabular}{llc}
\hline Designation & $\begin{array}{c}\text { Melting } \\
\text { Temp. }\left({ }^{\circ} \mathrm{C}\right)\end{array}$ & $\begin{array}{c}\text { Freezing } \\
\text { Temp. }\left({ }^{\circ} \mathrm{C}\right)\end{array}$ \\
\hline IP Petrolatum & 65.6 & -- \\
IP-2 Slack Wax & $44.4-51.7$ & $48.4-46.2$ \\
\hline
\end{tabular}

Changes in enthalpy of fusion and melting temperature under melt-freeze cycling conditions will be determined when a differentlal scanning calorimeter (DSC) becomes avallable.

Preliminary measurements on the viscosity of $\mathrm{Na}_{2} \mathrm{~S}_{2} \mathrm{O}_{3} \cdot 5 \mathrm{H}_{2} \mathrm{O}$ over the temperature range 36 to $66^{\circ} \mathrm{C}$ indicate viscosities about $20 \%$ higher than reported by Moynihan. ${ }^{2}$ This property is needed in calculations of thermal performance and may help in correlating super-cooling behavior.

\section{INDUSTRIAL PARTICIPATION (TASK 3)}

The following subcontracts are being developed:

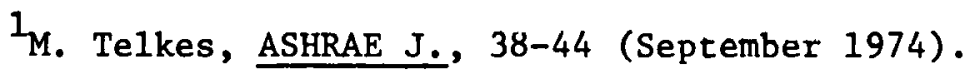

${ }^{2}$ C. T. Moynihan, J. Phys. Chem., 70, 3399 (1966). 


\begin{tabular}{|c|c|c|}
\hline & Organization & Subcontract Title \\
\hline 1. & Clemson University & $\begin{array}{l}\text { Immiscible Fluid-Heat of Fusion Heat } \\
\text { Storage System }\end{array}$ \\
\hline 2. & Dow Chemical Company & $\begin{array}{l}\text { Macro-Encapsulation of Heat Storage } \\
\text { Phase-Change Materlals for Use In } \\
\text { Residential Buildings }\end{array}$ \\
\hline 3. & Franklin Institute & $\begin{array}{l}\text { Thermal Energy Storage with Saturated } \\
\text { Aqueous Solutions }\end{array}$ \\
\hline 4. & Monsanto Resparsh Corporation & $\begin{array}{l}\text { Foru-stable Crystalliue Pnlimer Yollcto } \\
\quad \text { for Thermal Energy Storage }\end{array}$ \\
\hline 5. & Suntek Research Associates & $\begin{array}{l}\text { Thermorrete, A Thermal Energy Storage } \\
\text { Material with Structural and Thermo- } \\
\text { static Properties }\end{array}$ \\
\hline
\end{tabular}

Plans are being made to visit each of these subcontractors as the contracts are completed to meet personnel assigned, discuss the technical approach, view equipment and facllities, establish appropriate communication channels, and clarify technical and administrative relationships. As currently understood, ORNL wi11. follow and advise on the work being done but w111 suggest changes in scope, schedules, or budgets only through ESS Thermal \& Chemical Storage Branch.

\section{PROGRAM MANAGEMENT (TASK 1)}

\subsection{Subcontracts}

Procurement packages were processed by ERDA-ORO for the subcontracts 1isted above under Task 3 (Section 4). The Monsanto contract has been signed; the other four are still being negotiated, and signing early in the $T Q$ is anticipated.

\subsection{Proposal Reviews}

During the pertod January-June 1976, 13 unsolicited proposals were. recelved for review. Detailed comments and recommendations were provided on ten of these; review remains incomplete on three others. These proposals are listed in Table 76-6.1. 
Table 76-6.1 Unsolicited Proposals Reviewed, January-June 1976

Submitting Organization

1. Chemical Energy Specialists

2. Dow Chemical Comparry

3. EXYON Research and Engineering Company

4. Lockheed Missiles and Space Company, Incorporated

5. Monsanto Research Corporation

6. Pioneer Rural Elec $=$ ic Coop, Incorporated

$\because$ Science Applicatiozs, Incorporated

8. Southwest Research Inst1tute

9. S tandun, Inccrporated

10. State University of New York at Binghamton

11. UOP, Incorporated

12. University of Delaware

13. Westinghouse Research Laboratories

\section{Proposal Title}

The Chemical Heat Pump: A Simple Means to Conserve Energy

Developrent of Thermal Storage. Systems for the Heating and Cooling of Residential Bufldings:

(a) Macroencapsulation

(b) High-Temperature Storage for Absorption Air Conditioners

(c) Dispersed Storage

Water in 011 Liquid Emulsions - A Novel Technology for Energy Conservation and Storage in AirConditioning Applications

Development of Standardized Tests of Energy Storage Materials (EMS's) Performance

High-Temperature Thermal Energy Storage System, $\mathrm{Na}_{2} \mathrm{SO}_{4}+\mathrm{SO}_{3} \rightleftarrows \mathrm{Na}_{2} \mathrm{~S}_{2} \mathrm{O}_{7}$

Adapting off-Peak Banked Heat for Residential lise

Energy Storage in Reversible Decomposition Oxides

An Investigation of Thermal Energy Storage in Phase-Change Materials

The Use of Supercooled Fluids for Energy Storage in Solar Heating Applications

Search for Chemical Additives that Will Increase the Heat Capacity of Water

Dispersed Sal.ts Thermal Energy Storage

Research in Energy Storage Materials and Systems

Development of a Fluidized-Bed Device to Evaluate Experimental. Encapsulated Phase-Change Materials

\section{Review Status}

Review completed; letter to ERDA $2 / 19 / 76$

Review completed; letter to ERDA $6 / 10 / 76$

Review completed; letter to ERDA $6 / 8 / 76$

Review completed; letter to ERDA $3 / 15 / 76$

Review completed; letter to ERDA 6/9/76

Review completed; letter to ERDA $3 / 11 / 76$

Review completed; letter to ERDA $2 / 6 / 76$

Review completed; letter to ERDA $6 / 22 / 76$

Review completed; letter to ERDA $3 / 22 / 76$

Review completed; letter to ERDA $6 / 17 / 76$ 
On February 25-27, 1976, H. W. Hoffman assisted the Solar Heating and Cooling Branch (Division of Solar Energy) in the review of proposals for TES applicable to the solar heat source. During the following week, R. J. Kedl worked with C. J. Swet to prepare procurement packages for a number of the proposals found acceptable from this review (see listing In Section 4 above).

On March 30, 1976, H. W. Hoffman part1cipated (as Program Area Manager for Bullding Heating and Cooling Applications) in a review of the ANL program: Ammonia-Water Absorption System and Thermal Energy Storage. It was concluded that storage in the working fluid of an adsorption heating/cooling system was not the most cost-effective process.

\subsection{Meet1ngs}

Program staff participated during the last six months in a number of meetings relevant to the TES area:

a. Conference on Thermal Energy Storage. H. W. Hoffman was an Invited participant in this conference sponsored by the NATO Sclence Committee at Turnberry, Scotland, on March 1-5, 1976. The final report of this meeting has just been published (E. G. Kovach, Editor, Thermal Energy Storage, Sclent1fic Affairs Division, North Atlant1c Treaty Organization, Brussels, Belgium). The Summary from this report is appended (A-1); additional coples of the full report have been ordered.

b. Advanced TES Technologies for Solar Applications. R. J. Ked1 participated in this workshop held in Baton Rouge, Inuisiana, on April 2324, 1976, chalring discussion in the area of storage for onlar space heating and cooling. (This workshop - organized by the TES Branch, CONRT immedlately followed the Second Southeastern Conference on Application of Solar Energy co-sponsored by ERDA.) A summary of this duscussion area has been prepared by Kedl and forwarded to Professor Ozer Arnas (LSU) for inclusion in a report documenting the workshop results; a draft of this report is expected by early August.

c. Molten Salt Technology. H. W. Hoffman participated as one of four lecturers in a short course on Molten Salt Technology offered by the Center for Professional Development, East Brunswick, New Jersey, May 24-26, 
1976. These lectures covered the areas of engineering thermophysical properties, molten salt heat transfer and flow characteristics, and systems and components. One thrust was the application of molten salts as storage and heat transfer media for high-temperature TES. No formal documentation is planned.

\subsection{Visits}

Program staff members were involved in the following visits during this reporting period:

a. March 8-11, 1976. H. W. Hoffman - in the company of P. A. Lowe (ERDA-CONRT) and D. R. Glenn (GE-Valley Forge Space Center) - visited a number of European laboratories engaged in TES studies. These visits, made in the week following the NATO Conference discussed above (Section 5.3), were to the Philips Research Laboratorles in Aachen, Germany, and Eindhoven, Netherlands, and to Electriclté de France (EDF) in Chatou, France. Meetings were also held with U.S. Embassy staff, ERDA office personnel, and European Economic Community staff in Brussels, Belgium. Summaries of these visits are contalned in a trip report prepared by H. W. Hoffman.

b. April 27-28, 1976. S. Cantor (ORNL Chemistry Division) and J. R. Engel (ORNL Reactor Division) participated in a technical review by ERDA-DSE of the TES subsystem in the Honeywell, Incorporated, concept of a solar thermal-electric power station. Immediately prior to this review, the concept was discussed with Honeywell staff in Minneapolis. These visits are documented in a trip report by Cantor and Engel.

\subsection{Publications}

There were no formal publications during this reporting period. The draft of a report on snlar TES subsystems was forwarded (in early February) through CONRT-TES to the Congressional office of Technology Assessment. This report was prepared in partial response to OTA's request for Information on TES systems to support their study on solar energy utilization status and prospects (see Section 3.2). 


\subsection{Program Plan}

Preparation was started on a program plan for "Development of Advanced Thermal Energy Storage Systems for Bullding Heating and Cooling Applications." This plan supplements the natlonal program plan on TES (preliminary draft of February 16, 1976) by fllling in the detalls of technical activities proposed by ORNL to accomplish the national goals in the area of building heating and cooling.

A draft of this plan will be submitted for ERDA review and comment in the transition quarter. 
Appendix A-1

Excerpt from "Thermal Energy Storage," a report of a NATO Science Committee Conference at Turnberry, Scotland, March 1-5, 1976.

\section{$\underline{\text { Summary }}$}

The following is not meant as a complete summary of these findings. Rather, it represents general conclusions reached by the Organizing Committee.

1. It is clear that TES is far from new. In many instances it has been practiced for centuries. However, the concerted application of TES as a large-scale means of energy conservation has only been studied for the past few years, and no really new experimental results are yet available. This Conference was immensely useful in that it came at a most opportune time and served to order and clarify the thoughts of many responsible for directing future progress.

2. There are a large number of present and potential applications of TES; e.g., uses were identified in:

(a) Domestic heating

(b) Commercial heating (apartment houses, shopping centers, office buildings, etc.)

(c) Energy conservation in a large array of industrial applications

(d) Load leveling in the power generating industry.

3. In many instances the technologies involved in TES are well known and can be applied economically at present. This is particularly true for TES at temperatures below $100^{\circ} \mathrm{C}$ but also applies to sensible heat storage using water at higher temperatures and pressures.

4. Al1 Working Groups identified applications where the technology was known but acceptance of the principle would require pilot-scale development unfts. The initiation of such projects should be encouraged.

5. Long-range developments in materials for sensible heat and latent heat storage as well as for chemical storage, especlally at higher temperatures, offer exciting possibilities. 
6. The scale of storage both in terms of time and volume (or mass) of material is very important. Nearly all applications today are for hourly, diurnal or weekly storage and have immediate application in energy conservation, particularly in industry but also in domestic and commercial heating, and in the electric utilities for load leveling. However, there is a great need for seasonal storage - 1.e.. over many months - and the use of large lakes, ponds, or underground aquifers should be developed as rapidly as possible. This is mainly a low-tomoderate temperature application, and the "pay-off" in terms of energy savings is large.

7. While energy storage may be useful for clectric utilities, espectally for load leveling, it is mandatory for the development of solar heat and solar power applications.

8. It is clear that the Impact of TES on various systems is a most complex matter in which the economic answer depends on not only on technology but also on social and political considerations. It was unanimously agreed that while general guldelines were apparent it was impossible to examine specific cases because the optimum application for $a$. given instance depended strongly on the particular circumstances; the recommended procedure could be diametrically opposite for another case.

9. As a consequence, it was strongly recommended that detalled economic investigations of Individual cases be made before taking decisions. These should consider all variables, and the use of proven mathematical models would be a useful and indeed necessary prerequisite.

10. Although this conference concentrated on the needs of Industrially advanced nations, many participants expressed the view that TES would play a significant role in those countries in which technological development 1s underway. 


\section{INTERNAL DISTRIBUTION}

1. C. E. Bamberger

2. S. E. Beall

3. H. R. Bronstein

4. W. R. Busing

5. R. M. Canon

6. S. Cantor

7. W. B. Cottrell

8. J. R. Engel

9. G. G. Fee

10. L. M. Ferris

11. H. C. Fischer

12. M. H. Fontana

13. W. Fulkerson

14. J., R. Hightower

15-24. H. W. Hoffman

25. L. Jung

26. R. J. Kedl

27. R. E. MacPherson

28. W. R. Mixon

29. J. C. Moyers
30. H. Postma

31. L. I. Radcliffe (ORO)

32. M. W. Rosenthal

33. C. L. Segaser

34. C. D. Scott

35. A. Solomon

36. I. Spiewak

37. D. G. Thomas

38. I. L. Thomas

39. D. B. Trauger

40. G. D. Whitman

41. D. G. Wilson

42 43. Central Research Library

44. Document Reference Section

45 47. Laboratory Records

48. Laboratory Records, RC

49. ORNL Patent Office

50. ORNL Energy Information Center

51. ORNL R\&D Information Center

\section{EXTERNAL DISTRIBUTION}

52. J. G. Asbury, Argonne National Laboratory, 9700 South Cass Ave., Argonne, IL 60439

53. J. Bredehoef, U.S.G.S., Reston, VA 22070

54. D. Chahroudi, Suntek Research Associates, 500 Tamal Vista, Corte Madera, CA 94925

55. D. D. Edie, Chemical Engineering Department, Clemson University, Clemson, SC 29631

56. Catherine Goddard, ESS-Applications Analysis Branch, U.S. Energy Research and Development Administration, Washington, D.C. 20545

57. P. J. Graf, TRW Energy Systems Group, 7600 Colshire Drive, McLean, VA 22101

58. J. Hallett, Desert Research Institute, SAGE Building, Stead Campus, Reno, NV 89507

59. G. A. Lane, Dow Chemical Company, Larkin Laboratory, Midland, MI 48640 
60. H. G. Lorsch, The Franklin Institute, 20th and Parkway, Philadelphia, PA 19103

61. P. A. Lowe, Century 21, Building A-1, Room 504, Office of Internal Review, U.S. Energy Research and Development Administration, Germantown, $M D 20767$

62. R. W. Mar, Sandia Laboratories-Livermore, Livermore, CA 94550

63. Alan Michaels, Argonne National Laboratory, 9700 South Cass Avenue, Argonne, IL 60439

64. F. H. Morse, Solar Heating and Cooling Branch, Solar Energy Division, U.S. Energy Research and Development Maministration, Washington, D.C. 20545

65. W. J. Musica, NASA-Lewis Research Center, Cleveland, OH 44101

66. G. E. Pezdirtz, U.S. Energy Research and Development Administration, Washington, D.C. 20545

67. S. L. Sargent, Solar Heating and Cooling Branch, Solar Energy Division, U.S. Energy Research and Development Administration, Washington, D.C. 20545

68. I. O. Salyer, Monsanto Research Corporation, 1515 Nicholas Road, Dayton Laboratory, Dayton, OH 45407

69. F. J. Salzano, Brookhaven National Laboratory, Ụpton, NY 11973

70. F. W. Schmidt, Mechanical Engineering Department, Pennsylvania State University, University Park, PA 16802

71. C. J. Swet, Thermal Energy Storage, Division of Energy Storage Systems, U.S. Energy Research and Development Administration, Washington, D.C. 20.54 .5$.

72. J. H. Swisher, Thermal Energy Storage, Division of Energy Storage Systems, U.S. Energy Research and Development Administration, Washingt.nn, D. . . ? $, 5,4,5$

73. Maria Telkes, Institute of Energy Conversion, University of Delaware, Newark, DE 19711

74. J. C. Warman, Water Resources Research Institute, Auburn University, Alzburn, AI 36803

75. G. H. Watson, Lockheed-Huntsville Research and Engineering Branch, 4800 Bradford Drive, Huntsville, AL 35807 
76. S. W. Yuan, George Washington University, Washington, D.C. 20007

77. Director, Research and Technical Support Division, ERDA, ORO 78-104. Technical Information Center, Oak Ridge, TN 37830 